\title{
Pemikiran Ibnu Qayyim Al-Jauziyyah \\ Tentang Wali Mujbir dalam Pernikahan (Perspektif Hak Asasi Anak)
}

\author{
Ahmad Rasyid \\ IAIN Palangka Raya \\ Ahmadrasyid153@gmail.com
}

\begin{abstract}
One of the major contributions of Ibn Qayyim is about wali mujbir guardian in marriage. He expressed a parent or guardian should not be married off forcibly if it is not accompanied with the consent and approval of the child. This perspective is different from the scholarly (the majority of scholars) that states a parent or guardian may be married off forcibly although without the consent and approval of the child. This study is a literature study (library research) using a contextual approach presented in descriptive and deductive. Data were analyzed through content analysis and hermeneutic methods and study uṣul fiqh. Results from this study: (1) Especially girls (as well as boys) should not be forced to marry and must not be married except with his/her agreement. (2) The Method used legal istinbāt. (3) Relevance thought Ibn Qayyim Al-Jawziyya about mujbir guardian in marriage (a child's right perspective) in accordance with the spirit of child rights and relevant to contemporary conditions. Thought Ibn Qayyim are considered able to accommodate the growing problems of law in society in order to avoid forcing the parents to their children to marry without first requested permission and consent of the child.
\end{abstract}

Keywoards: the view ibn qayyim al-jawziyya, the child rights

\section{A. Pendahuluan}

Wali dalam istilah fikih adalah orang yang memiliki kekuasaan untuk melakukan tas \}arruf (pengaturan) tanpa tergantung pada izin orang lain. ${ }^{1}$ Berdasarkan definisi tersebut terkandung makna bahwa wali merupakan seseorang yang secara hukum mempunyai otoritas terhadap seseorang karena mempunyai kompetensi untuk menjadi pelindung dan melakukan perbuatan hukum, baik bagi dirinya ataupun bagi orang lain.

Wali dihubungkan dengan hukum perkawinan adalah seseorang yang bertindak atas nama mempelai perempuan dalam pelaksanaan akad nikah. Akad nikah tersebut dilangsungkan oleh kedua mempelai, yaitu pihak laki-

${ }^{1}$ Waḥbah az-Zuhailī, Al-Fiqh Al-Islamī Wa Adilatuh Juz. VII, Damaskus: Dār al-Fikr, 1989, h. 186. 
laki yang dilakukan oleh mempelai laki-laki itu sendiri dan pihak perempuan yang dilakukan/diwakili oleh walinya. ${ }^{2}$

Terdapat beberapa ayat Alquran dan hadis mengenai kedudukan wali dalam hukum perkawinan Islam. Hal tersebut sebagaimana dalam surat alBaqarah [2] ayat 221 dan $232^{3}$ serta an-Nur [24] ayat $32 .{ }^{4}$ Selain itu, ketentuan wali juga dimuat dalam beberapa hadis Rasulullah Saw.

Kedudukan wali juga diatur dalam Undang-Undang Nomor 1 Tahun 1974 Tentang Perkawinan, Peraturan Pemerintah Nomor 9 Tahun 1975 Tentang Pelaksanaan Undang-Undang Nomor 1 Tahun 1974 Tentang Perkawinan serta Instruksi Presiden RI Nomor 1 Tahun 1991 Tentang Kompilasi Hukum Islam. Secara substantif, ketentuan hukum tersebut mencerminkan nilai hukum Islam dalam sistem hukum positif di Indonesia, terutama mengenai pentingnya kedudukan dan peran wali dalam perkawinan.

Terdapat perdebatan pemikiran yang cukup dinamis mengenai kedudukan wali, dalam hal ini peran wali nikah bukan hanya terkait dengan masalah keabsahan pernikahan seseorang. Namun, juga mengenai hak menikahkan orang yang berada di bawah perwaliannya serta terkait dengan masalah perizinan bagi orang yang akan melakukan pernikahan. Terlebih, jika seorang wali melakukan pemaksaan terhadap anaknya atau seseorang yang berada di bawah perwaliannya untuk menikah dengan orang lain tanpa keinginan atau persetujuan anak, baik terhadap anak perempuan bahkan anak laki-laki. Dalam hal ini, wali tersebut disebut wali mujbir.

Persoalan yang muncul kemudian adalah ketika dalam praktiknya, perbuatan memaksa dari seorang wali yang berlindung dibalik hak ijbār hanya dijadikan sebagai alat untuk memaksa anaknya menikah dengan pilihan walinya tersebut tanpa disertai izin dan rasa rida dari anak atau orang yang berada di bawah perwaliannya. Berkenaan dengan ketentuan wali mujbir tersebut, mayoritas ulama fikih, seperti kalangan Mālikiyah, Syāfi‘iyah, Ḥanabilah serta

\footnotetext{
${ }^{2}$ Amir Syarifuddin, Hukum Perkawinan di Indonesia, Jakarta: Kencana, 2007, h. 77.

${ }^{3}$ Kementerian Agama Islam, Wakaf, Dakwah dan Irsyad Kerajaan Saudi Arabia, Mujamma' al-Mālik Fahd Li Tiba 'at al-Muṣhaf..., h. 53-54.

${ }^{4}$ Ibid., h. 594.
} 
Zahiriyah membolehkan hak ijbār dilakukan seorang wali terhadap anak maupun orang yang berada di bawah perwaliannya untuk menikah meskipun tanpa disertai izin anak tersebut. ${ }^{5}$

Berbeda halnya dengan Ibnu Qayyim al-Jauziyyah yang menyatakan bahwa seorang wali tidak boleh memaksa anaknya untuk menikah kecuali dengan persetujuan dan rida anak tersebut. Meskipun seorang wali mempunyai kekuasaan untuk menikahkan anak maupun orang yang berada di bawah perwaliannya. Hal tersebut tidak mutlak dilakukan seorang wali jika terdapat unsur pemaksaan yang menyebabkan tidak adanya rasa rida oleh anak dalam rangka pernikahannya. ${ }^{6}$

Menjadi semakin menarik ketika pandangan Ibnu Qayyim tentang wali yang tidak boleh melakukan pemaksaan kehendaknya terhadap anak maupun seseorang yang berada di bawah perwaliannya untuk menikah tersebut dihubungkan dengan wacana global yang berkembang saat ini dalam lingkup hak asasi manusia (HAM), ${ }^{7}$ terutama jika ditinjau dalam perspektif hak asasi anak. Konsep ijbār (paksaan) tersebut dapat menjadi polemik disebabkan adanya kesan yang menjadikan wali sebagai seseorang yang otoriter terhadap anaknya maupun orang yang berada di bawah perwaliannya dalam hal pernikahan. Seyogyanya orang tua juga perlu memperhatikan dan mempertimbangkan pandangan serta keinginan anak. Sebab pada hakikatnya, anak juga mempunyai hak atas keberlangsungan hidupnya ke depan. Mengingat di Indonesia juga sudah memberlakukan Undang-Undang Nomor

${ }^{5}$ Lihat Muhammad Jawad Mugniyah, Fiqih Lima Mazhab, alih bahasa Masykur A.B dkk dari kitab asli yang berjudul al-Fiqh 'ala al-Mażahib al-Khamsah, Jakarta: Lentera, 2008, h. 346.

${ }^{6} \mathrm{Abu}$ Abdillah Syamsuddin Muhammad bin Abū Bakar bin Ayyub bin Sa'ad bin Huraiz bin Mak̄̄ Zainuddin az-Zar'i ad-Dimasyqīi Ibnu Qayyim al-Jauziyyah, Zādul Ma'ā fì Had̄̄ Khairil 'Ibād, Beirut: Dār al-Kutub al-Ilmiyah, 2007, Cet. II, h. 702.

${ }^{7}$ Prinsip pokok hak asasi manusia sudah tertuang dalam ajaran Islam melalui Piagam Madinah yang berisi pertama, semua pemeluk Islam adalah satu umat walaupun mereka berbeda suku bangsa. Kedua, hubungan antara komunitas Muslim dengan nonmuslim di dasarkan pada prinsip yang salah satunya saling menasihati. Lahirnya deklarasi Kairo juga disemangati oleh pesan inklusif Piagam Madinah yang diantaranya berisi tentang hak persamaan dan kebebasan, hak berkeluarga, hak kesetaraan wanita dengan pria juga hak memperoleh perlakuan yang sama. Lihat A. Ubaedillah dan Abdul Rozak, Pendidikan Kewarganegaraan: Pancasila, Demokrasi, HAM dan Masyarakat Madani, Jakarta: Kencana, 2013, Cet. X, h. 167.

Jurnal Studi Agama dan Masyarakat

Volume 12, Nomor 2, Desember 2016 
23 Tahun 2002 Tentang Perlindungan Anak serta Undang-Undang Nomor 39 Tahun 1999 Tentang Hak Asasi Manusia.

Adanya perbedaan pendapat di kalangan para ahli hukum Islam (fikih) tentang status wali mujbir merupakan ranah ijtihadiyah yang penting untuk diapresiasi dan diteliti secara mendalam sebagai upaya mengaktualisasikan nilai-nilai hukum di bidang perkawinan Islam karena realitas yang berkembang di kalangan masyarakat saat ini masih mungkin terjadi unsur pemaksaan yang dilakukan seorang wali dalam menikahkan anaknya atau orang yang berada di bawah perwaliannya.

Berdasarkan latar belakang tersebut, penelitian ini bertujuan mengkaji secara mendalam mengenai pemikiran Ibnu Qayyim al-Jauziyyah tentang wali mujbir yang dalam hal ini pendapatnya berbeda dengan pendapat mayoritas ulama fikih. Kemudian, pemikirannya tersebut dihubungkan dengan kondisi kekinian dalam lingkup hak asasi anak. Pembahasan ini peneliti tuangkan dalam skripsi dengan judul: Pemikiran Ibnu Qayyim AlJauziyyah Tentang Wali Mujbir Dalam Pernikahan (Perspektif Hak Asasi Anak).

\section{B. Kajian Pustaka}

Kurniati $^{8}$ membahas tentang pandangan Ibnu Qayyim al-Jauziyyah sebagai pembaharu di kalangan mazhab Hanbali, terutama pemikirannya tentang pemurnian ajaran Alquran dan sunnah serta ajakannya untuk berijtihad secara bebas, namun tetap pada koridor ajaran maqāṣid syari'ah yang bermuara pada prinsip kemaslahatan manusia. Adapun fokus penelitian ini mengenai pandangan Ibnu Qayyim al-Jauziyyah di bidang jināyat (pidana Islam), terutama mengenai hukum potong tangan. Pada dasarnya Ibnu Qayyim al-Jauziyyah sependapat dengan praktik yang dilakukan Umar bin Khattab. Menurutnya, setiap pencuri tidak mesti dihukum dengan potong tangan meskipun segala persyaratan untuk potong tangan itu terpenuhi. Kesemuanya itu akan gugur ketika kondisi objektif yang dialami oleh pencuri

${ }^{8}$ Kurniati, "Pemikiran Ibnu Qayyim al-Jauziyyah Tentang Pengaruh Perubahan Sosial", Al-Risalah, Vol. 10, No. 1, Mei 2010, h. 115-126. 
itu tidak memungkinkan untuk dilaksanakan hukuman had, misalnya dalan hal perang atau paceklik. Tentunya hal tersebut didasarkan pada prinsip kemaslahatan manusia.

Munir Salim ${ }^{9}$ mengurai tentang pandangan Ibnu Qayyim mengenai keadilan dalam konteks politik hukum (siyāsah syar'iyyah). Konteks tersebut meliputi kesadaran penguasa yang dalam taraf tertentu memiliki wewenang dalam penjabaran dan penambahan aturan hukum Islam sepanjang sesuai dengan jiwa syariah. Ibnu Qayyim al-Jauziyyah membagi keputusankeputusan hukum yang dihasilkan oleh kekuasaan politik (siyāsah) menjadi dua, yaitu adil dan zalim. Dalam hal ini, Ibnu Qayyim al-Jauziyyah menolak pembedaan antara siyāsah dan syariah, melainkan mengajukan cara pembedaan lain, yaitu adil dan zalim. Menurut Ibnu Qayyim al-Jauziyyah, adil adalah syariah, sedangkan zalim adalah antitesis terhadap syariah. Penelaahan selanjutnya dikemukakan oleh Hardi Putra Wirman ${ }^{10}$ yang mengkomparasi pemikiran Ibnu Hazm dan Ibnu Qayyim al-Jauziyyah tentang pendekatan analogi (qiȳ̄s) dalam penetapan hukum Islam. Ibnu Hazm yang bermazhab Zahiri dalam menetapkan hukum berdasarkan pada Alquran, hadis dan ijmak serta konsep ad-dalīl yang dalam hal bukan dalam bentuk qiyās, tetapi dalam bentuk lain yang tidak berpegang pada illah fiqhiyyah, namun didasarkan pada istilah-istilah logika. Sedangkan, Ibnu Qayyim al-Jauziyyah dari kalangan Hanabilah dalam menetapkan hukum menerima qiyās sebagai salah satu sumber hukum Islam, selain Alquran, hadis dan ijmak. Dalam kesimpulannya, diungkapkan bahwa Ibnu Hazm cenderung tekstual dalam menyikapi persoalan hukum. Sedangkan, Ibnu Qayyim terkesan liberal dalam menggunakan akal. Dengan demikian, seharusnya ada langkah seimbang yang harus diambil oleh umat Islam, yakni menggabungkan pendapat Ibnu Hazm dan pandangan Ibnu Qayyim al-Jauziyyah, sehingga hukum Islam akan

\footnotetext{
${ }^{9}$ Munir Salim, "Keadilan dan Kebenaran menurut Hukum Islam”, Al-Daulah, Vol. 3, No. 1, Juni 2014, h. 105-116.

${ }^{10}$ Hardi Putra Wirman, "Problematika Pendekatan Analogi (Qiyas) dalam Penetapan Hukum Islam: Telaah atas pemikiran Ibnu Hazm dan Ibnu Qayyim al-Jauziyyah", Asy-Syir'ah: Jurnal Ilmu Syari'ah dan Hukum, Vol. 47, No. 1, Juni 2013, h. 26-46.
} 
selalu relevan atas pelbagai kondisi. Dengan demikian, ajaran Islam dapat terus menjadi rahmatan lil 'ālamīn. Peneliti sendiri mengambil sudut lain dalam penelitian terhadap pemikiran Ibnu Qayyim al-Jauziyyah yang menekankan pada bidang munākahat mengenai ketentuan wali mujbir dalam pernikahan beserta metode istinbāt hukumnya. Dalam hal ini pendapatnya berbeda dengan pendapat mayoritas ulama fikih. Lebih lanjut, juga diuraikan mengenai relevansi pemikiran Ibnu Qayyim al-Jauziyyah tersebut dengan kondisi saat ini dalam lingkup hak asasi anak. Kemudian, dipadukan dengan ketentuan perundang-undangan yang berlaku di Indonesia.

\section{Metode Penelitian}

Penelitian ini disebut sebagai penelitian kepustakaan (library research), yaitu penelitian yang dilakukan melalui bahan-bahan pustaka atau literatur-literatur kepustakaan sebagai sumber tertulis. Lebih spesifik, penelitian ini juga disebut penelitian normatif. Data-data dikumpulkan dengan menggunakan teknik penelaahan terhadap referensi-referensi yang relevan dengan permasalahan yang diteliti sebagai cara pemecahan permasalahan, serta dengan ide-ide baru dalam khazanah keilmuan Islam. ${ }^{11}$ khususnya terkait dengan pemikiran Ibnu Qayyim al-Jauziyyah tentang wali mujbir dalam pernikahan (perspektif hak asasi anak).

Pendekatan yang digunakan dalam penelitian ini adalah pendekatan kontekstual dan historis yang melihat keterkaitan masa lampau, kini dan mendatang. Masa lampau digunakan sebagai pemaknaan historis, masa kini digunakan pemaknaan fungsional di masa sekarang dan masa mendatang digunakan untuk pemaknaan di kemudian hari. ${ }^{12}$ Penelitian mengenai pemikiran Ibnu Qayyim al-Jauziyyah mengenai wali mujbir (perspektif hak asasi anak) menurut peneliti tepat digunakan pendekatan seperti ini, baik dalam kaitannya dengan pemikiran Ibnu Qayyim al-Jauziyyah pada masanya atau relevansinya dengan masa sekarang bahkan di masa yang akan datang.

\footnotetext{
${ }^{11}$ Bambang Sunggono, Metodologi Penelitian Hukum, Jakarta: PT. RajaGrafindo Persada, 1998, h. 114 - 115. Lihat pula Suharsimi Arikunto, Manajemen Penelitian, Jakarta: Rineka Cipta, 1990, h. 81.

${ }^{12}$ Noeng Muhadjir, Metodologi Penelitian Kualitatif, Yogyakarta: Rake Sarasin, 2000, h. 263.
} 


\section{Pembahasan}

Meskipun jumhur ulama membolehkan penggunaan hak ijbār (wali gairu mujbir) yang dilakukan oleh seorang wali terhadap anaknya maupun terhadap seseorang yang berada di bawah perwaliannya, namun Ibnu Qayyim al-Jauziyyah berpendapat bahwa orang tua atau wali tidak boleh memaksa anaknya atau seseorang yang berada di bawah perwaliannya untuk menikah kecuali dengan persetujuan dan rida/kerelaan anak terlebih dulu. Meskipun orang tua atau wali mempunyai kekuasaan untuk menikahkan anak maupun orang yang berada di bawah perwaliannya. Namun, hal tersebut tidak mutlak dilakukan jika terdapat unsur paksaan yang menyebabkan tidak adanya kesediaannya oleh anak dalam rangka perkawinannya. Ibnu Qayyim alJauziyyah mengemukakan pandangannya sebagai berikut:

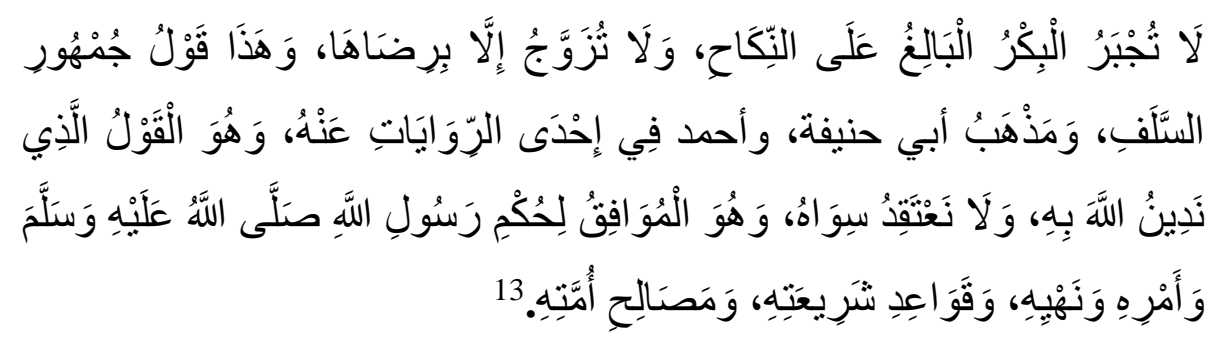

"Wanita gadis yang sudah balig tidak boleh dipaksa dalam masalah pernikahan dan tidak boleh dinikahkan kecuali dengan ridanya. Ini merupakan pendapat jumhur salaf, mazhab Abū Hanīfah dan Ạmad dalam salah satu riwayat. Inilah yang memang sejalan dengan hukum Rasulullah Saw, perintah dan larangan beliau, kaidah-kaidah syariat serta kemaslahatan umat".

Dalam pencermatan peneliti, perlunya persetujuan seorang anak dalam memilih pasangan sebagaimana diungkapkan Ibnu Qayyim alJauziyyah di atas, didasarkan pada hadis tentang penolakan seorang gadis untuk dinikahkan walinya. ${ }^{14}$ Lebih lanjut, Ibnu Qayyim juga menguatkan

\footnotetext{
${ }^{13}$ Ibnu Qayyim al-Jauziyyah, Zādul Ma'ad fì Had̄̄ Khairil 'Ibād, Beirut: Dār al-Kutūb al-Ilmiyah, 2007, Cet. II, h. 703.

${ }^{14}$ Hadis Riwayat Ibnu Mājah Nomor 1875 Lihat :Abū Abdullah Muhammad bin Yazid alQazwini Ibnu Mājah, Ensiklopedia Hadis 8: Sunan Ibnu Mājah, alih bahasa Saifuddin Zuhri, Jakarta: Penerbit Almahira, 2013, Cet. I, h. 333.
} 
pendapatnya dengan mengemukakan hadis lainnya tentang janda yang tidak boleh dipaksa untuk dinikahkan oleh walinya. ${ }^{15}$

Dilandasi berbagai hadis di atas, Ibnu Qayyim al-Jauziyyah menyatakan bahwa penggunaan hak ijbār tidak seharusnya dilakukan orang tua terhadap anaknya.

Terkait dengan pemikiran Ibnu Qayyim al-Jauziyyah tentang wali mujbir dalam pernikahan tentunya perlu menekankan pada pendekatan yang ia gunakan dalam penetapan hukumnya. Sehingga pendekatan pemikiran Ibnu Qayyim al-Jauziyyah merupakan polarisasi antara naql (naș) dan aql (rasio). Selain itu, corak pemikirannya cenderung rasional, mendasar, mapan secara syar'i, argumentatif serta konsisten.

Mengenai konteks wali mujbir dalam pernikahan menurut pandangan Ibnu Qayyim al-Jauziyyah bahwa orang tua atau wali tidak berhak memaksa anak atau orang yang berada di bawah perwaliannya untuk menikah tanpa diminta izin dan persetujuannya terlebih dulu, Ibnu Qayyim menilai keridaan dan persetujuan anak, khususnya anak perempuan harus ada memberikan respon dalam prosesi penjajakan awal perkawinan (peminangan). Hal ini dimaksudkan karena pada hakikatnya yang akan menjalani biduk rumah tangga setelah pernikahan ke depannya adalah si anak dan bukan orang tuanya.

Ada beberapa dasar yang digunakan Ibnu Qayyim al-Jauziyyah sebagai landasan normatif dalam konstruksi epistomologi pemikiran hukum (istinbāt $t$ ). Beberapa dasar tersebut meliputi Al-Quran, sunah, ijmak, fatwa Sahabat, qiyas, mașlahah mursalah, istișhāb, sadd aż-żarì'ah dan 'urf.

Adapun metode istinbāt hukum yang digunakan Ibnu Qayyim al-Jauziyyah dalam menetapkan ketentuan wali mujbir tersebut didasarkan pada beberapa hadis Rasulullah Muhammad Saw mengenai penolakan pernikahan yang dilakukan orang tua terhadap anak yang masih

${ }^{15}$ Lihat Hadis Șaḥih al-Bukhāri Nomor 5138 dan 6946 Lihat: Abu Abdillah Muhammad bin Ismail al-Bukhāri, Șah̄̄h al-Bukhāri, Beirut: Dār al-Fikr, 2006, h. 265. serta Hadis Ṣah̄̄h Muslim Nomor 1421 Lihat Abū Husein Muslim, Șahih Muslim Juz II, Beirut: Dār al-Fikr, 2011, h. 650. 
gadis/perawan serta anak yang sudah janda meskipun tanpa disertai izin anak sebelumnya, sebagai berikut:

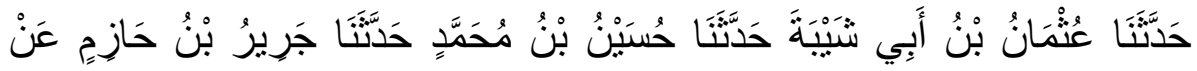

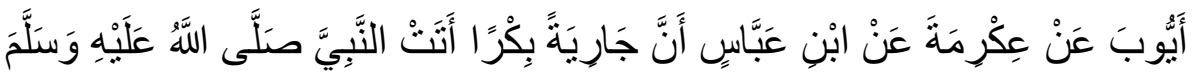

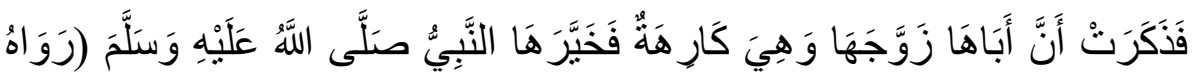

$$
\begin{aligned}
& 16 \text { (ابَوْ دَاوُدَ) }
\end{aligned}
$$

"Telah menceritakan kepada kami Utsman bin Abū Syaibah, telah menceritakan kepada kami Husain bin Muhammad, telah menceritakan kepada kami Jarīr bin Ḥāzim, dari Ayyub, dari Ikrimah dari Ibnu 'Abbās, bahwa seorang gadis datang kepada Nabi șallallahu 'alaihi wasallam dan menyebutkan bahwa ayahnya telah menikahkannya sementara ia tidak senang. Kemudian beliau memberikan pilihan" (H.R. Abū Dāwud).

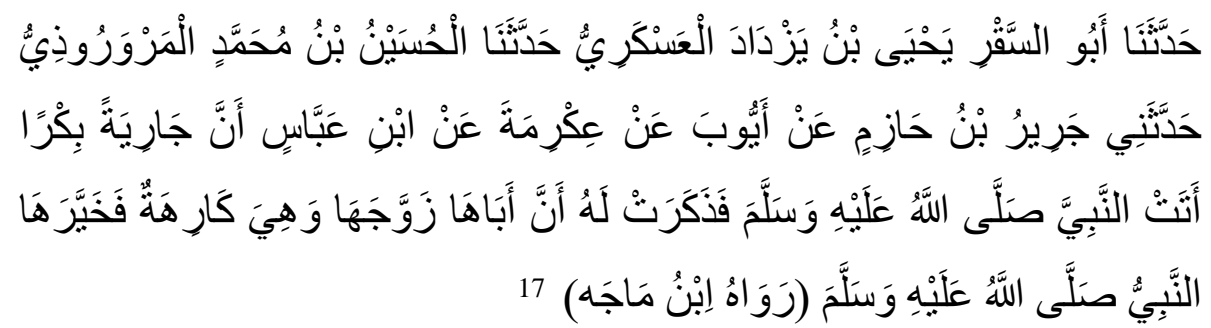

"Telah menceritakan kepada kami Abū As-Saqr Yahya bin Yazdād alAskari berkata, telah menceritakan kepada kami al-Husain bin Muhammad al-Marwarudzi berkata, telah menceritakan kepadaku Jarīr bin Hāzim dari Ayyub dari Ikrimah dari Ibnu Abbas berkata, "Seorang budak wanita yang masih gadis mendatangi Nabi șallallahu 'alaihi wasallam, ia mengabarkan bahwa ayahnya telah menikahkannya dengan seseorang yang tidak ia sukai, hingga Rasulullah șallallahu 'alaihi wasallam memberikan pilihan untuknya" (H.R. Ibnu Mājah)

${ }^{16}$ H.R. Imam Abū Dāwud Nomor 2096. Lihat As-Sijistani, Abū Dāwud Sulaiman bin alAsy 'aș al-Azdi, Sunan Abī Dāwud Juz II, Beirut: Dār al-Fikr, 1994, h. 192. Lihat juga Abū Dāwud Sulaiman bin al-Asy’ats al-Azdi as-Sijistani, Ensiklopedia Hadis: Sunan Abu Dawud Jilid V, alih bahasa Muhammad Ghazali, Penerbit Almahira, 2013, Cet. I, h. 431.

${ }^{17}$ Hadis Imam Ibnu Mājah Nomor 1875 Lihat: Abū 'Abdullah Muhammad bin Yazīd al-Qazwini Ibnu Mājah, Ensiklopedia Hadis: Sunan Ibnu Majah Jilid VIII, alih bahasa Saifuddin Zuhri, Jakarta: Penerbit Almahira, 2013, Cet. I, h. 333. 
Hadis mengenai janda yang berhak memilih calon pendampingnya:

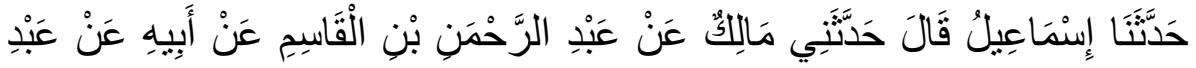

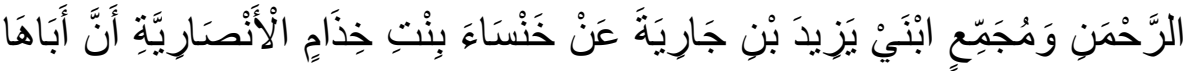

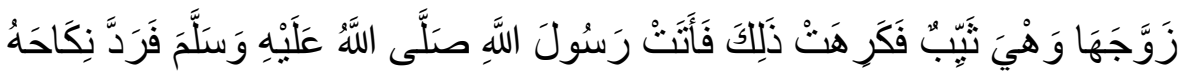

$$
\begin{aligned}
& 18 \text { (رَوَاهُ البُخَارِى }
\end{aligned}
$$

"Telah menceritakan kepada kami Isma'il ia berkata; Telah menceritakan kepadaku Mālik dari 'Abdurraḥman bin al-Qāsim dari bapaknya dari Abdurrahman dan Mujammi' keduanya anak Yazīd bin Jāriyah, dari Khansā binti Khizām al-Anșariyyah bahwa bapaknya menikahkannya saat ia janda, lalu ia pun tak suka. Lalu ia pun mendatangi Rasulullah șallallahu 'alaihi wasallam, maka beliau pun menolak pernikahannya”. (H.R. Bukhāri)

Hadis mengenai anak yang tidak boleh dipaksa untuk menikah:

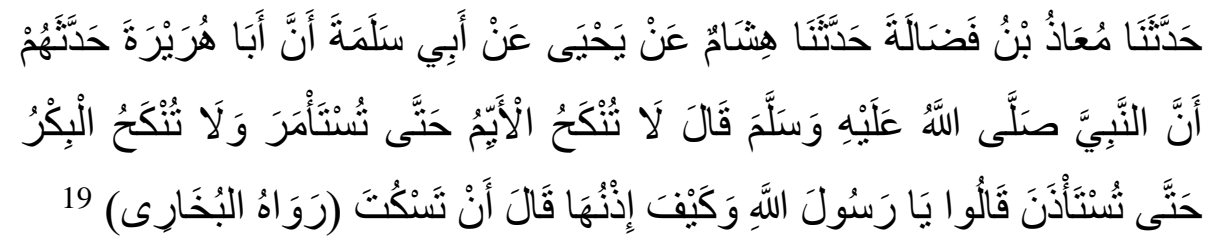

"Telah menceritakan kepada kami Mu'aż bin Faḍalah, telah menceritakan kepada kami Hisyām dari Yahya dari Abī Salamah bahwa Abū Hurairah menceritakan kepada mereka bahwa Nabi șallallahu 'alaihi wasallam bersabda: "Seorang janda tidak boleh dinikahi hingga ia dimintai pendapatnya, sedangkan gadis tidak boleh dinikahkan hingga dimintai izinnya." Para sahabat bertanya, "Wahai Rasulullah, seperti apakah izinnya?" beliau menjawab: "Bila ia diam tak berkata" (H.R. Bukhāri)

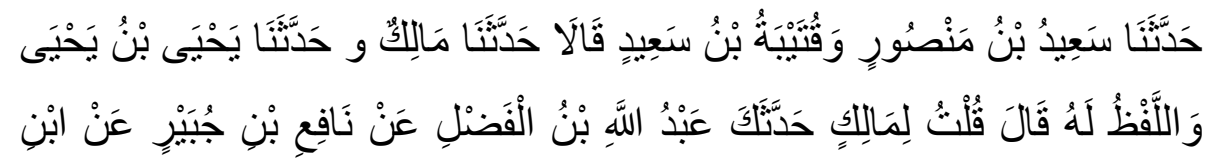

\footnotetext{
${ }^{18}$ Hadis Sahīh al-Bukhāri Nomor 5138. Lihat Abū 'Abdillah Muhammad bin Ismail al-Bukhāri, Șaḥ̄h al-Bukhāri, Beirut: Dār al-Fikr, 2006, h. 265.

${ }^{19}$ Hadis Șahīh al-Bukhāri Nomor 5136. Ibid., h. 265.
} 


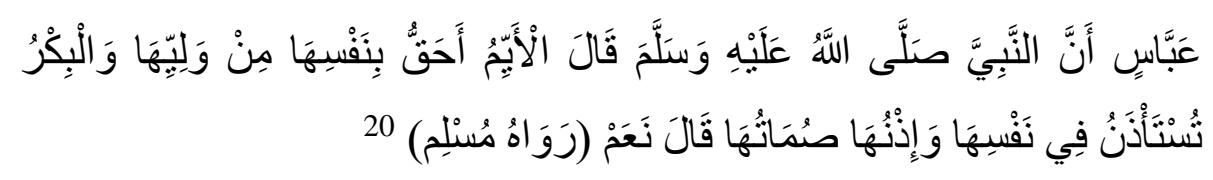

"Telah menceritakan kepada kami Sa'id bin Manșur dan Qutaibah bin Sa'id keduanya berkata; telah menceritakan kepada kami Mālik dan diriwayatkan dari jalur lain, telah menceritakan kepada kami Yahya bin Yahya sedangkan lafaẓnya dari dia (Yahya), dia berkata; Saya bertanya kepada Mālik; Apakah 'Abdullah bin Fadll pernah menceritakan kepadamu dari Nāfi' bin Jubair dari Ibnu 'Abbās bahwa Nabi șallallahu 'alaihi wasallam telah bersabda: "Seorang janda lebih berhak atas dirinya daripada walinya, sedangkan anak gadis harus di mintai izin darinya, dan izinnya adalah diamnya?" Dia menjawab; "Ya". (H.R. Muslim)

Dilandasi berbagai hadis di atas, Ibnu Qayyim al-Jauziyyah menyatakan bahwa penggunaan hak ijbār tidak seharusnya dilakukan orang tua terhadap anaknya. Dalam hal ini, orang tua atau wali tidak berhak untuk memaksa anak atau seseorang yang berada di bawah perwaliannya untuk menikah, sebelum diminta izin dan persetujannya terlebih dulu.

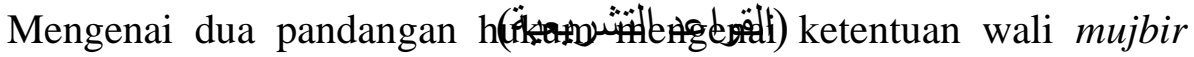
dalam pernikahan, baik I (القواعد اللغوية) Ilama maupun menurut Ibnu Qayyim al-Jauziyyah sama-sama memiliki landasan naṣ yang argumentatif. Terkait hal itu, istinbāt al-ahkām dalam memahami naș tersebut ditempuh melalui penggunaan kaidah-kaidah lugawiyah yakni dari segi bahasanya dan kaidah-kaidah tasyri'iyyah, yakni dari segi ruh atau semangat ajarannya. ${ }^{21}$

Ulama ușul fikih dalam menyelesaikan pertentangan antara dua dalil hukum, setidaknya beranjak dari salah satu kaidah yang berbunyi:

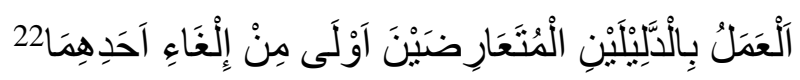

Mengamalkan dua dalil yang berbenturan lebih baik daripada mengabaikan salah satu di antara keduanya. Berkenaan dengan perbedaan dasar hukum tentang wali mujbir antara dasar yang digunakan oleh jumhur ulama fikih

\footnotetext{
${ }^{20}$ Hadis Șah̄inh Muslim Nomor 4121. Lihat Abū Husein Muslim, Șah̄inh Muslim, Beirut: Dār al-Fikr, 2011, Jilid 2, h. 650.

${ }^{21}$ A. Djazuli, Ușul Fiqh (Metodologi Hukum Islam), Jakarta: RajaGrafindo Persada, 2000, h. 231 .

${ }^{22}$ Amir Syarifuddin, Ușul Fiqh Jilid I, Ciputat: Logos Wacana Ilmu, 1997, h. 208.
} 
dengan Ibnu Qayyim al-Jauziyyah, hal tersebut termasuk dalam ranah ta'ārud al-adillah. ${ }^{23}$ Terminologi ta'ārud al-adillah dapat diartikan sebagai pertentangan antara kandungan salah satu dari dua dalil yang sama derajatnya dengan kandungan dalil yang lain yang mana salah satu diantara dua dalil tersebut menafikan hukum yang ditunjuk oleh dalil yang lainnya.

Metode istinbāt Ibnu Qayyim al-Jauziyyah tentang wali mujbir dalam pernikahan didasari atas polarisasi antara naql (naș) dan aql (rasio) atau disebut juga dengan istilah aqlāniyyah syar'iyyah (rasionalisme legal) guna menemukan indikasi-indikasi yang mengarah pada hukum asal dengan pertimbangan rasional terhadap hadis mengenai wali mujbir dapat dibenarkan validitasnya. Berdasarkan konstruksi pemikiran Ibnu Qayyim ditemukan bahwa secara eksplisit Alquran tidak menyinggung mengenai wali mujbir yang boleh memaksakan anaknya menikah meskipun tanpa diminta izin dan persetujuan anak terlebih dulu. Namun, pada sejumlah hadis dapat ditemukan konteks wali mujbir yang menggunakan hak ijbār. Selain itu, dalam beberapa hadis juga dibahas tentang kebebasan anak, terutama anak perempuan dalam menentukan pasangan hidupnya.

Berkenaan dengan konteks wali mujbir, secara normatif-teoritis pada dasarnya tidak ada pijakan yang eksplisit diatur Alquran. Alquran hanya memuat asas dan norma yang sangat umum tentang persoalan perkawinan. Ketentuan wali mujbir dapat ditemukan dalam perspektif hadis. Meskipun banyak versi dan riwayat yang terkait dengan konteks wali mujbir, namun secara substantif menekankan adanya persetujuan anak, terutama anak perempuan dan kebebasan untuk menentukan pasangan hidup.

Sama halnya dalam domain fikih, meskipun beragam pendapat antara yang pro dan kontra terhadap konsep wali mujbir, namun pada dasarnya konsep ijbār dalam perspektif ulama bukanlah pemaksaan yang semena-

${ }^{23}$ Pada umumnya, terdapat 4 (empat) pembagian ta'ārud al-adillah, yaitu 1. Pertentangan antara dalil naș Alquran dengan Alquran; 2. Pertentangan antara dalil as-Sunnah dengan as-Sunnah; 3. Pertentangan antara dalil as-Sunnah dengan al-Qiyas; serta 4. Pertentangan antara dalil Qiyas dengan Qiyas. Lihat Rahmat Syafe'i, Ilmu Ușul Fiqh untuk UIN, STAIN dan PTAIS, Bandung : Pustaka Setia, 1998, h. 225. 
mena yang tidak bertanggung jawab, akan tetapi lebih merupakan hak bagi orang tua untuk mengarahkan putra-putrinya supaya dapat hidup bahagia. Adapun persoalan yang muncul dalam tataran praktik, tindakan paksa orang tua atau wali dalam pernikahan anaknya sangat berpotensi menimbulkan aspek-aspek negatif yang dapat berujung pada berakhirnya hubungan rumah tangga anak. Karena itu, Ibnu Qayyim berpendapat bahwa tindakan paksa orang tua atau wali dalam pernikahan anaknya tanpa disertai izin dan pendapatnya tidak dapat dibenarkan.

Peneliti mencermati bahwa konsepsi yang ditawarkan Ibnu Qayyim tersebut lebih relevan digunakan untuk memecahkan problematika yang berkembang di tengah masyarakat. Hal itu disebabkan setiap anak, baik lakilaki maupun perempuan mempunyai hak yang sama dalam memilih jodoh dan menentukan siapa yang akan menjadi pendampingnya di masa depan demi keharmonisan, kebahagiaan, ketenangan, dan ketentraman dalam kehidupan keluarganya kelak.

Meskipun anak diberi kebebasan memilih calon pasangannya, namun tidak serta merta menafikan peran orang tua. Dengan mengenyampingkan hak ijbar, bukan berarti setiap anak akan bebas secara absolut untuk memilih calon pendamping hidup. Sebab, bagaimanapun juga berbagai saran dan nasihat yang baik dan positif dari orang tua tetap penting untuk menjadi perhatian seorang anak. Terlebih lagi, dalam urusan pernikahan yang bukan hanya menyatukan dua pribadi yang berbeda, namun juga menyatukan dua buah keluarga besar.

Pandangan Ibnu Qayyim yang menyatakan seorang wali yang tidak boleh melakukan pemaksaan terhadap anak maupun seseorang yang berada di bawah perwaliannya untuk menikah tanpa diminta izin dan persetujuan anak terlebih dulu sejalan dengan wacana global yang berkembang saat ini dalam konteks Hak Asasi Manusia (HAM), terutama jika ditinjau dari perspektif Hak Asasi Anak (HAA). Anak juga mempunyai hak atas keberlangsungan hidupnya ke depan, termasuk mengenai pernikahannya. Apalagi di Indonesia kini juga sudah memberlakukan Undang-Undang Nomor 23 Tahun 2002 Tentang 
Perlindungan Anak serta Undang-Undang Nomor 39 Tahun 1999 Tentang Hak Asasi Manusia.

Hak Asasi Manusia (HAM) adalah terjemahan dari human rights. Pengertian human rights menyangkut perlindungan terhadap seseorang dari penindasan oleh siapapun, negara atau bukan negara. Sedangkan, pengertian basic right menyangkut perlindungan seorang warga negara atau penduduk dari penindasan oleh negara. Hak Asasi Manusia (HAM) merupakan hak yang melekat pada diri setiap manusia sejak awal dilahirkan yang berlaku seumur hidup dan tidak dapat diganggu gugat oleh siapapun. ${ }^{24}$ Merujuk pada ketentuan Pasal 1 Undang-Undang Nomor 39 Tahun 1999 Tentang HAM dinyatakan bahwa Hak Asasi Manusia (HAM) adalah seperangkat hak yang melekat pada hakikat dan keberadaan manusia sebagai makhluk Tuhan Yang Maha Esa dan merupakan anugerah-Nya yang wajib dihormati, dijunjung tinggi dan dilindungi oleh negara, hukum, pemerintah dan setiap orang demi kehormatan serta perlindungan harkat dan martabat manusia.

Konvensi tentang Hak Anak mengatur 4 (empat) hal pokok yang dimiliki seorang anak, yaitu hak untuk hidup (survival rights), hak berkembang (development rights), hak mendapat perlindungan (protection rights) dan hak berpartisipasi (participation rights). Hak anak bertujuan guna memastikan setiap anak memiliki kesempatan untuk mencapai potensi mereka secara penuh dan dapat berkembang tanpa diskriminasi serta memiliki akses di berbagai aspek kehidupan. ${ }^{25}$

\footnotetext{
${ }^{24}$ Qurrotul Ainiyah, Keadilan Gender dalam Islam: Konvensi PBB dalam Perspektif Mazhab Syafi'i, Malang: Intrans Publishing, 2015, h. 44.

${ }^{25}$ Prinsip-prinsip Konvensi Hak Anak antara lain: 1. Non-diskriminasi dan kesempatan yang sama Semua anak memiliki hak yang sama. 2. Kepentingan terbaik dari anak Kepentingan terbaik bagi anak harus menjadi pertimbangan utama ketika membuat keputusan yang mungkin berdampak pada anak. Ketika orang dewasa membuat keputusan mereka harus berfikir bagaimana keputusan mereka itu berdampak pada anak-anak. 3. Hak untuk hidup, kelangsungan hidup dan perkembangan Anak mempunyai hak untuk hidup. Anak harus memperoleh perawatan yang diperlukan untuk menjamin kesehatan fisik, mental, dan emosi mereka serta juga perkembangan intelektual, sosial, dan kultural. 4. Partisipasi Anak mempunyai hak untuk mengekspresikan diri dan didengar. Mereka harus memilik kesempatan untuk menyatakan pendapat tentang keputusan yang berdampak pada mereka dan pandangan mereka harus dipertimbangkan. Lihat Absori, "Perlindungan Hukum Hak-hak Anak dan Implementasinya di Indonesia pada Era Otonomi
} 
Mengenai orang tua atau wali yang tidak boleh memaksa anaknya menikah tanpa diminta izin dan persetujuannya terlebih dulu juga selaras dengan Pemikiran Ibnu Qayyim al-Jauziyyah tentang wali mujbir dalam pernikahan. Hal itu disebabkan pada hakikatnya Islam tidak mengajarkan sikap pemaksaan (otoritarianisme) dan diskriminatif terhadap sesama manusia, terutama bagi anak. Bahkan, Islâm sangat mempertimbangkan nilainilai persamaan, kesetaraan (al-musāwah), dan kebebasan (al-hurriyah) dalam menyelesaian problem-problem keagamaan. Setiap individu diberikan keleluasaan untuk melakukan perbuatan hukum dengan penuh rasa tanggung jawab, termasuk dalam urusan pernikahan.

Apabila dicermati lebih lanjut, pemikiran Ibnu Qayyim al-Jauziyyah tentang wali mujbir dalam pernikahan mengandung nilai-nilai filosofis, diantaranya:

* Nilai Kemaslahatan, yakni dapat memelihara kemaslahatan dan menjaga hak-hak yang dimiliki oleh anak yang akan menikah;

* Nilai Persamaan, yakni tidak ada diskriminasi atas dasar jenis kelamin. Laki-laki dan perempuan mempunyai kesempatan yang sama untuk memilih dan menentukan calon pasangan hidupnya;

* Nilai Musyawarah. Wali tidak berhak memaksakan kehendaknya untuk menentukan pasangan hidup bagi sang anak. Baik, orang tua maupun anak dan keluarga besar harus bermusyawarah untuk memilih yang terbaik bagi sang anak;

* Nilai Kebijaksanaan. Guna menentukan pasangan hidup, menjadi bijaksana jika anak tetap meminta pertimbangan orang tua atau wali. Hal itu disebabkan perkawinan itu juga menyatukan dua keluarga besar.

* Nilai Kebebasan. Dengan memberi kebebasan pada anak untuk menentukan calon pasangan hidupnya, anak tersebut bisa lebih menghargai dan menghormati orang tua atau walinya karena diberi kepercayaan untuk menentukan calon pasangannya;

Daerah", Fakultas Hukum Universitas Muhammadiyah Surakarta: Jurisprudence, Vol. 2, No. 1, 2005, h. 80-83. 
* Nilai Keadilan. Dengan tidak adanya diskriminasi atas dasar jenis kelamin, strata sosial dalam memilih calon pasangan hidup serta memandang bahwa orang tua atau wali dan anak punya hak dan kewajiban yang berimbang, maka keadilan akan tercapai;

* Nilai Kesejahteraan. Indonesia merupakan Negara hukum dan segala sesuatu yang ada dalam masyarakat diatur dalam perundang-undangan. Dengan adanya aturan hukum dan perundang-undangan diharapkan bisa melindungi hak-hak anak dan menjamin kesejahteraan masyarakat.

Pemikiran Ibnu Qayyim al-Jauziyyah tentang wali mujbir dalam pernikahan tersebut juga sejalan dengan semangat Hak Asasi Manusia (HAM), utamanya dalam lingkup Hak Asasi Anak (HAA). Karena itu, pemikiran Ibnu Qayyim tersebut relevan untuk diaplikasikan saati ini, baik di Indonesia maupun di berbagai negara lainnya. Terlebih nilai-nilai pemiikiran Ibnu Qayyim tersebut juga sudah tertuang dalam aturan perundang-undangan yang berlaku di Indonesia.

Adapun yang perlu menjadi perhatian saat ini adalah tentang praktik pernikahan di tengah-tengah masyarakat yang mungkin masih terjadi pemaksaaan yang dilakukan orang tua terhadap anaknya. Sehingga, melalui upaya preventif seperti sosialisasi Undang-Undang Perkawinan diharapkan dapat membuka wawasan masyarakat untuk mencegah terjadinya pernikahan paksa. Karena, sejatinya pernikahan haruslah didasari keridaan dan persetujuan dari kedua calon mempelai. Dengan demikian, tujuan pernikahan guna membentuk keluarga yang bahagia dan kekal dalam nuansa sakinah, mawaddah dan rahmah dapat terwujud, sehingga dapat memperoleh keberkahan dan keridaan Allah Swt.

Pada akhirnya, Peneliti menilai bahwa Pemikiran Ibnu Qayyim al-Jauziyyah tentang wali mujbir dalam pernikahan yang ditinjau dari perspektif Hak Asasi Anak (HAA) tersebut mengandung nilai hukum progresif dan humanis. Selain itu, melalui formulasi pemikiran Ibnu Qayyim tersebut, diharapkan dapat memberikan kontribusi yang signifikan bagi upaya reformasi hukum keluarga Islam dewasa ini agar sejalan dengan tujuan 
pembentukan hukum Islam (maqāsisid syari'ah) serta senantiasa berdasarkan pada prinsip dasar ajaran Islam yang universal dalam konteks rah matan lil 'ālamìn.

\section{E. Kesimpulan}

Beranjak dari pembahasan yang telah diuraikan sebelumnya mengenai Pemikiran Ibnu Qayyim Al-Jauziyyah tentang Wali Mujbir dalam Pernikahan (Perspektif Hak Asasi Anak), maka dalam penelitian ini disimpulkan sebagai berikut; Latar Belakang Ibnu Qayyim Al-Jauziyyah tentang wali mujbir dalam pernikahan menyatakan bahwa seorang anak, terutama anak perempuan (demikian juga dengan anak laki-laki) tidak boleh dipaksa untuk menikah serta tidak boleh dinikahkan kecuali dengan ridanya. Dengan demikian, orang tua atau wali tidak boleh menikahkan secara paksa terhadap anak maupun orang yang berada di bawah perwaliannya apabila tidak terlebih dulu disertai dengan izin dan persetujuan anak. Relevansi Pemikiran Ibnu Qayyim Al-Jauziyyah tentang Wali Mujbïr dalam Pernikahan (Perspektif Hak Asasi Anak) sesuai dengan semangat Hak Asasi Manusia (HAM), terutama dalam lingkup Hak Asasi Anak (HAA) serta relevan dengan kondisi saat ini, baik di Indonesia maupun di berbagai negara muslim lainnya. Dengan demikian, pemikiran Ibnu Qayyim tersebut dinilai mampu mengakomodir problematika hukum yang berkembang di masyarakat, guna menghindari pemaksaan yang dilakukan orang tua terhadap anaknya untuk menikah tanpa terlebih dulu diminta izin dan persetujuan anak.

\section{Daftar Pustaka}

Ainiyah, Qurrotul, Keadilan Gender dalam Islam: Konvensi PBB dalam Perspektif Mazhab Syafi'i, Malang: Intrans Publishing, 2015.

Mughniyah, Muhammad Jawad, Fiqih Lima Mazhab : Ja'fari, Hanafi, Maliki, Syafi'i dan Hambali, alih bahasa Masykur A.B. dari kitab asli Al-Fiqh 'ala al-Madzāhib al-Khamsah, Jakarta: Lentera, 2005, Cet. 13.

Muhadjir, Noeng, Metodologi Penelitian Kualitatif, Yogyakarta: Rake Sarasin, 2000. 
Sunggono, Bambang, Metodologi Penelitian Hukum, Jakarta: PT RajaGrafindo Persada, 1998.

Syarifuddin, Amir, Ushul Fiqh Jilid I, Ciputat: Logos Wacana Ilmu, 1997.

----------, Ușul Fiqh Jilid 2, Ciputat: Logos Wacana Ilmu, 1999.

---------, Hukum Perkawinan di Indonesia, Jakarta: Kencana, 2007.

---------, Ușul Fiqh, Jakarta: Kencana Prenada Media Group, 2009, Cet. 4 Jilid 1.

Salim, Munir, "Keadilan dan Kebenaran menurut Hukum Islam”, Al-Daulah, Vol. 3, No. 1, Juni 2014.

Kurniati, "Pemikiran Ibnu Qayyim al-Jauziyyah Tentang Pengaruh Perubahan Sosial”, Al-Risalah, Vol. 10, No. 1, Mei 2010.

Ubaedillah, A. dan Abdul Rozak, Pendidikan Kewarganegaraan: Pancasila, Demokrasi, HAM dan Masyarakat Madani, Jakarta: Kencana, 2013, Cet. 10.

Wirman, Hardi Putra, "Problematika Pendekatan Analogi (Qiyas) dalam Penetapan Hukum Islam: Telaah atas pemikiran Ibnu Hazm dan Ibnu Qayyim al-Jauziyyah", Asy-Syir'ah: Jurnal Ilmu Syari'ah dan Hukum, Vol. 47, No. 1, Juni 2013. 